\title{
Vírus respiratório sincicial bovino
}

\author{
Bovine respiratory syncytial virus
}

Fernando Rosado Spilki ${ }^{1} \&$ Clarice Weis Arns ${ }^{2}$

\begin{abstract}
RESUMO
O Vírus Respiratório Sincicial Bovino (BRSV) é uma causa importante de doença respiratória, principalmente em bovinos jovens, caracterizada por pneumonia intersticial. A distribuição das infecções pelo BRSV é mundial e o vírus foi identificado em diferentes episódios no Brasil. O vírus pertence ao gênero Pneumovirus da família Paramyxoviridae e o seu genoma RNA não-segmentado de sentido negativo codifica para 10 proteínas. As proteínas de fusão (F) e de adesão (G) constituem os principais alvos para o sistema imune do hospedeiro. Esse fato deve estar relacionado com a grande variabilidade destas proteínas e de seus genes correspondentes, conforme determinado tanto por anticorpos monoclonais quanto por análise filogenética com base em sequiências de nucleotídeos. A transmissão, resposta imune e patogenia das infecções pelo BRSV, foram estudadas no hospedeiro natural sob condições naturais e experimentais; todavia, alguns aspectos da imunobiologia da infecção são ainda pouco conhecidos. O uso de modelos experimentais, especialmente roedores, pode fornecer novas informações sobre esse assunto. O estado atual do diagnóstico laboratorial das infecções e as medidas de controle para prevenir surtos de BRSV também são apresentados e discutidos.
\end{abstract}

Descritores: vírus respiratório sincicial bovino, BRSV, doenças de bovinos.

\begin{abstract}
Bovine respiratory syncytial virus (BRSV) is a major cause of respiratory disease, mainly in young cattle, characterized by interstitial pneumonia. Distribution of BRSV infections is worldwide and the virus has been identified in different episodes in Brazil. The virus belongs to the genus Pneumovirus of the Paramyxoviridae family and its negative sense non-segmented RNA genome encodes 10 proteins. Fusion $(\mathrm{F})$ and attachment $(\mathrm{G})$ proteins constitute the main target for immune responses of the host. This fact may be related to the great variability of these proteins and its corresponding genes among field isolates, as determined by both monoclonal antibodies and phylogenetic analysis using nucleotide sequences. Transmission, immune responses and pathogenesis of BRSV infections were studied in the natural host under natural and experimental conditions; however, some aspects regarding the immunobiology of infection are yet poorly understood. The use of experimental models of infection, especially rodents, may provide new information on these subjects. The present status on laboratory diagnosis of infections and control measures to prevent BRSV outbreaks are also presented and discussed.
\end{abstract}

Key words: bovine respiratory syncytial virus, BRSV, bovine diseases.

${ }^{1}$ Instituto de Ciências da Saúde, Centro Universitário Feevale (Feevale), Novo Hamburgo, RS/Brasil. ${ }^{2}$ Departamento de Microbiologia e Imunologia, Instituto de Biologia, Universidade Estadual de Campinas (UNICAMP), Campinas, SP/Brasil. CORRESPONDÊNCIA: F.R. Spilki [fernandors@feevale.br]. 


\section{INTRODUÇÃO}

O Vírus Respiratório Sincicial Bovino (BRSV) foi isolado pela primeira vez em 1967, a partir de casos de pneumonia em bovinos [120]. O BRSV tem distribuição mundial e causa severa doença respiratória em bovinos jovens, caracterizada por bronquiolite e pneumonia intersticial, de forma similar à enfermidade decorrente da infecção pelo Vírus Respiratório Sincicial Humano (HRSV) em crianças [92, 163].

\section{Classificação e estrutura}

O BRSV pertence ao gênero Pneumovirus, da família Paramyxoviridae, ordem Mononegavirales $[41,92,156]$. Essa ordem compreende vírus dotados de genoma composto de RNA de fita simples ("mono") com sentido negativo ("nega", nsRNA, sentido de leitura 3'-5') [72,127]. O BRSV está intimamente relacionado ao HRSV $[15,111,163]$, bem como aos vírus respiratórios sinciciais ovino e caprino (ORSV e CRSV) [35,154]. Tais vírus compartilham inúmeras características comuns, especialmente no que tange à organização genômica e estrutura viral $[3,35,98$, 154].

BRSV e HRSV são vírus pleomórficos, envelopados, de tamanho variável: as partículas esféricas medem entre 80 e $350 \mathrm{~nm}$ de diâmetro; as partículas filamentosas medem entre 60 e $100 \mathrm{~nm}$ de diâmetro, com aproximadamente $1 \mathrm{~mm}$ de comprimento [69, 71,156].

\section{Organização genômica}

As partículas infecciosas do BRSV contêm um genoma de RNA fita simples, não segmentado, de polaridade negativa, envolto por um complexo de nucleoproteína que protege o genoma da ação de RNAses celulares [32,184]. O genoma do BRSV, com aproximadamente 15.000 nucleotídeos, codifica 10 RNAs mensageiros (mRNA) subgenômicos [32,41, 92,184]. Cada um destes mRNAs contém uma única fase aberta de leitura (open reading frame, $\mathrm{ORF}$ ), à exceção do gene M2, que contém as ORFs M2-1 e M2-2 [41,160]. O RNA genômico é utilizado na síntese de mRNAs, que, por sua vez, são subseqüentemente traduzidos em novas proteínas virais; por outro lado, ocorre a síntese de antigenomas que irão servir como moldes na síntese de novo RNA genômico [100,160]. O RNA viral é transcrito em 10 mRNAs por uma RNA polimerase RNA-dependente, sendo que, cada mRNA, codifica para a tradução de uma proteína diferente [184]. A quantidade de cada mRNA está relacionada com a posição do gene no sentido 3'-5', havendo um maior acúmulo dos mRNAs quanto mais próximos os mesmos se encontram da extremidade 3' [114,160]. As proteínas são nomeadas conforme a ordem de aparecimento e distância da extremidade 3' na seqüência nucleotídica: NS1 (antes chamada 1C), NS2 (antes denominada 1B), N, P, M, SH (1A), $\mathrm{G}, \mathrm{F}, \mathrm{M} 2 \mathrm{e} \mathrm{L}$. Todos os mRNAs formados são dotados de um sítio CAP em sua extremidade 5' e poliadenilados na sua extremidade 3', sendo essas modificações finais do mRNA formado processadas pela polimerase viral $[40,119]$. Cada um dos genes tem uma sequiência de iniciação de 10 nucleotídeos, altamente conservada e termina com sequiências de 12 a 13 nucleotídeos que induzem a poliadenilação e liberação do mRNA viral completo $[32,122,132,186$, 187]. Regiões intergênicas estão presentes entre os genes, à exceção da junção entre os genes M2 e L, os quais se sobrepõem em 56 nucleotídeos [1,41, 186].

\section{Proteínas virais}

A proteína de fusão viral $\mathrm{F}$ é uma glicoproteína transmembrana inserida no envelope viral, sendo responsável pela penetração viral e formação de sincícios in vitro e in vivo [124,130,131]. A exemplo da proteína $\mathrm{F}$ de outros paramixovírus, estima-se que a proteína $\mathrm{F}$ de BRSV forme trímeros [67,121,124, 175]. A mesma é sintetizada no retículo endoplasmático rugoso como um precursor inativo (F0), formado por 574 resíduos de aminoácidos que, posteriormente, é clivado por proteases celulares na rede trans-Golgi, dando origem ao heterodímero F2-F1, que consiste nas subunidades protéicas ligadas por pontes dissulfeto [121,135,171]. Essa clivagem libera o denominado peptídeo de fusão $\left({ }_{131} \mathrm{KKRKRR}_{136}\right)$, um fragmento hidrofóbico localizado na região aminoterminal da subunidade F1, o qual está diretamente envolvido na inserção da proteína na membrana celular [135,158,171,188]. A proteína de fusão constitui o principal alvo do sistema imune do hospedeiro, sendo que apenas anticorpos direcionados contra a proteína $\mathrm{F}$ e a proteína de adesão $\mathrm{G}$ são capazes de neutralizar o BRSV $[37,47,88,141,144,174]$. A subunidade F2 é o determinante de especificidade nas infecções por vírus respiratórios sinciciais [135]. Em vírus com deleção induzida da proteína de adesão $\mathrm{G}$, 
a proteína $\mathrm{F}$ é capaz de realizar a adesão da partícula viral à membrana celular [76,135].

A proteína $\mathrm{G}$ é responsável pela adesão dos vírions à membrana celular do hospedeiro, já que na subfamília Pneumovirinae, ao contrário dos membros da subfamília Paramyxovirinae, não estão presentes as proteínas hemaglutinina e neuraminidase [37,88,89]. A proteína G é uma glicoproteína transmembrana do tipo II, já que sua região $\mathrm{N}$-terminal tende a expor-se para o citoplasma, enquanto seu fragmento C-terminal deve permanecer no lúmen do compartimento interno à membrana $[37,87,88]$. $\mathrm{O}$ mRNA que codifica a proteína $\mathrm{G}$ possui, aproximadamente, 838 nucleotídeos de extensão, excluindo a cauda de poli-A, e o mesmo codifica para um polipeptídeo formado de 257 resíduos de aminoácidos $[98,99,151]$. A massa molecular estimada é de 28,6 $\mathrm{kDa}$; todavia, a mesma apresenta-se variável quando avaliada quanto à migração em géis de poliacrilamida, dada a intensa glicosilação, semelhante à mucina, existente nas regiões amino e carboxiterminal da proteína, o que se teoriza seja uma maneira de facilitar a penetração do vírion através do muco para atingir o epitélio respiratório [92,159]. Tais regiões flanqueiam um domínio central, o qual é formado por 32 resíduos de aminoácidos, que apresenta uma estrutura denominada de nó de cisteínas, induzida pela presença de duas pontes dissulfeto formadas entre as quatro cisteínas presentes $[37,89]$. O nó de cisteínas parece ser importante na indução de eosinofilia pulmonar nas infecções por HRSV em modelos experimentais [20,60,61]. A proteína $G$ não é essencial à replicação viral in vitro, mas desempenha um importante papel na infecção in vivo [76, 135].

A proteína SH (do inglês small hydrofobic), é uma proteína integral de membrana inserida no envelope viral, cuja função é ainda desconhecida [76, 123,131]. A mesma associa-se em oligômeros que se acumulam nas membranas do Complexo de Golgi, que se associam, posteriormente, a regiões de permeabilidade, alterada na membrana, ricas em lipídios, os "lipid-rafts", e sua expressão em sistemas heterólogos altera a permeabilidade sugerindo que a proteína SH forme canais de membrana [132].

A proteína de matriz $\mathrm{M}$ é uma proteína nãoglicosilada, interna à partícula viral [2]. A proteína $\mathrm{M}$ é composta por 256 aminoácidos, com uma massa molecular de 28,7 kDa. A mesma, media a associação do nucleocapsídeo viral ao envelope da partícula $[132,175]$. A proteína é dotada de um domínio hidrofóbico na extremidade C-terminal (resíduos 188204), responsável pela interação da mesma com membranas biológicas [175].

As proteínas N, P e L podem ser co-precipitadas de suspensões virais na forma de nucleocapsídeos [81,86]. A nucleoproteína $\mathrm{N}$ se liga fortemente aos RNAs genômicos e antigenômicos na formação do nucleocapsídeo resistente às RNAses [86]. A proteína $\mathrm{N}$ é formada por 391 aminoácidos, sendo que seu peso molecular é de $43 \mathrm{kDa}$ [86]. A mesma apresenta altos níveis de identidade entre os isolados de BRSV e, destes, com outros paramixovírus, sendo altamente conservada $[21,86,159,179]$.

A fosfoproteína $\mathrm{P}$ atua como uma chaperonina para a forma solúvel da proteína $\mathrm{N}$ [79-81,97, 142]. A proteína $P$ ainda serve como um co-fator para a polimerase viral (L), após a sua fosforilação [79,80, 142,183]. A fosforilação da proteína $\mathrm{P}$ se deve ao alto conteúdo de resíduos de serina e treonina, que constituem, aproximadamente, $17 \%$ dos 241 aminoácidos da mesma [80]. Na ausência de fosforilação da proteína $\mathrm{P}$, a polimerase produz apenas uma série de oligonucleotídeos a partir da extremidade 3' do geno$\mathrm{ma}$, o que sugere que uma proteína $\mathrm{P}$ funcional é necessária para converter a polimerase viral nascente em um complexo estável [81,183,185].

A polimerase viral L é a fração mais importante do complexo RNA polimerase RNA-dependente [183]. Ao longo dos 2161 aminoácidos constituintes da proteína, podem ser encontrados quatro motivos conservados comuns a todas as RNA polimerases de paramixovírus [66,183].

As proteínas N, P e L são responsáveis e suficientes para a replicação do RNA viral [183]. Associada à replicação do RNA, pode ser ainda arrolada a proteína M2, cujo gene correspondente M2 apresenta duas ORFs [2,184,187]. Sabe-se que o polipeptídeo de 186 aminoácidos, codificado pela ORF1 (M2-1), atua na replicação viral, conferindo ao complexo RNA polimerase RNA-dependente um nível adequado de processividade ao impedir a terminação abrupta da síntese dos mRNAs virais [68]. A proteína M2-2 (95 aa) regula também a síntese de RNA, já que, vírus dotados de deleções artificialmente induzidas da proteína M2-2, apresentam taxas de transcrição aumentadas e baixas taxas de replicação in vitro $[68,183]$. 
Ao contrário de outros membros da família Paramyxoviridae, os vírus do gênero Pneumovirus apresentam ainda outros dois genes que codificam para proteínas não estruturais (NS1 e NS2) [62,122, 134,184]. As proteínas NS1 e NS2 inibem a síntese e ação de interferons (IFN) alfa e beta pela célula hospedeira, através do bloqueio da ativação do fator 3 do IFN e da inibição da expressão de Stat2, diminuindo a responsividade da célula à ação dos IFNs [23,24, 134,147,182].

\section{Replicação viral}

A adesão dos pneumovírus à célula é mediada pela ligação da proteína $\mathrm{G}$ a receptores celulares, os quais ainda não foram determinados; todavia, supõe-se que estes receptores sejam glicosaminoglicanos (GAGs) encontrados na matriz extracelular $[52,76]$. Essa etapa é provavelmente completada por uma segunda ligação da proteína $\mathrm{F}$, e talvez ainda da proteína $\mathrm{SH}$, a proteínas de superfície da membrana celular [135]. Conforme mencionado anteriormente, uma amostra de HRSV recombinante, com deleção dos genes $\mathrm{G}$ e $\mathrm{SH}$, pode multiplicar-se de forma eficiente in vitro, o que sugere que a proteína $\mathrm{F}$ pode mediar sozinha a ligação do vírus à célula hospedeira [135]. Após a adesão, o BRSV adentra a célula por fusão do envelope viral à membrana celular, mecanismo mediado pela proteína $F[27,41,58]$. O processo tem como resultado a entrada do nucleocapsídeo viral no citoplasma, domínio celular no qual irão se suceder todos os próximos passos da replicação do BRSV [41,58,92].

Já com o vírus inserido no ambiente intracelular, inicia-se a transcrição do genoma viral em mRNAs por ação do complexo RNA polimerase RNA-dependente. A RNA polimerase viral inicia a síntese de RNA na extremidade 3' do genoma, e os genes são transcritos de maneira seqüencial, terminando e reiniciando a cada uma das junções intergênicas [63,186,187]. Tão logo sucede uma região intergênica não transcrita, segue-se uma região inicial de um gene que determina a adição de um sítio 5'CAP e a iniciação da transcrição do mRNA. Ocasionalmente, o complexo RNA polimerase RNA-dependente falha em reiniciar a transcrição em genes localizados mais próximos à extremidade 5' do genoma, o que resulta em um gradiente de acúmulo dos mRNAs mais próximos ao início do genoma (3') [58]. A síntese de anti-genomas (5'-3'), que servirão de molde na síntese de novos genomas virais de polaridade negativa, inicia apenas após a tradução dos primeiros transcritos primários em proteínas virais $[32,184]$. A síntese dos anti-genomas é mediada pela mesma polimerase viral; todavia, na síntese destas cópias complementares ao genoma viral, o complexo enzimático ignora todas as junções gênicas $[32,33,58,184]$. Os antigenomas são de 10 a 20 vezes menos abundantes que o genoma viral em uma célula infectada; ainda assim, podem ser encontrados vírions empacotando essas moléculas intermediárias na síntese de novos genomas virais, pois não há um sinal específico de encapsidação [79]. Acredita-se que, de modo genérico, para os paramixovírus, a concentração de proteína $\mathrm{N}$, no meio celular, determine a mudança do estado de transcrição para a replicação do RNA viral [58].

A montagem dos nucleocapsídeos se dá no citoplasma, e acredita-se que a mesma ocorra em passos distintos [86,113]. Primeiramente, a proteína N livre se associa aos genomas ou antigenomas, formando um complexo ribonucleoproteína (RNP) de simetria helicoidal [86,113]. Na segunda etapa, as proteínas $\mathrm{P}$ e L se associam à RNP, formando o nucleocapsídeo [113]. A proteína $M$ direciona os nucleocapsídeos às regiões da membrana celular, ricas em proteínas de superfície viral, e mais apropriadas ao brotamento da partícula viral $[30,113]$. A maturação da partícula viral se dá na superfície da célula hospedeira [83,188], e os vírions permanecem firmemente aderidos à membrana celular [58].

\section{Variabilidade antigênica do BRSV}

As diferenças entre isolados de BRSV, analisadas por intermédio de anticorpos monoclonais, permitiram evidenciar a presença de três diferentes subgrupos antigênicos, denominados $\mathrm{A}, \mathrm{AB}$ (ou Intermediário) e B $[56,57,94,105,138]$. Ocorrem ainda isolados que não se enquadram nesta classificação [56,57,94,105,138,140]. As implicações práticas dessa diversidade, quanto à patogenicidade e imunoprofilaxia, ainda não foram devidamente estudadas, mas, uma amostra com diferenças significativas na proteína G, pôde conferir proteção clínica a animais posteriormente infectados com uma amostra heteróloga, ainda que os mesmos tenham apresentado excreção viral considerável $[39,140]$.

Esta diversidade antigênica tem correlação com o que é encontrado em análises genômicas, conforme o tipo de análise filogenética utilizado e a sequiência gênica alvo abordada na comparação [56,130, 


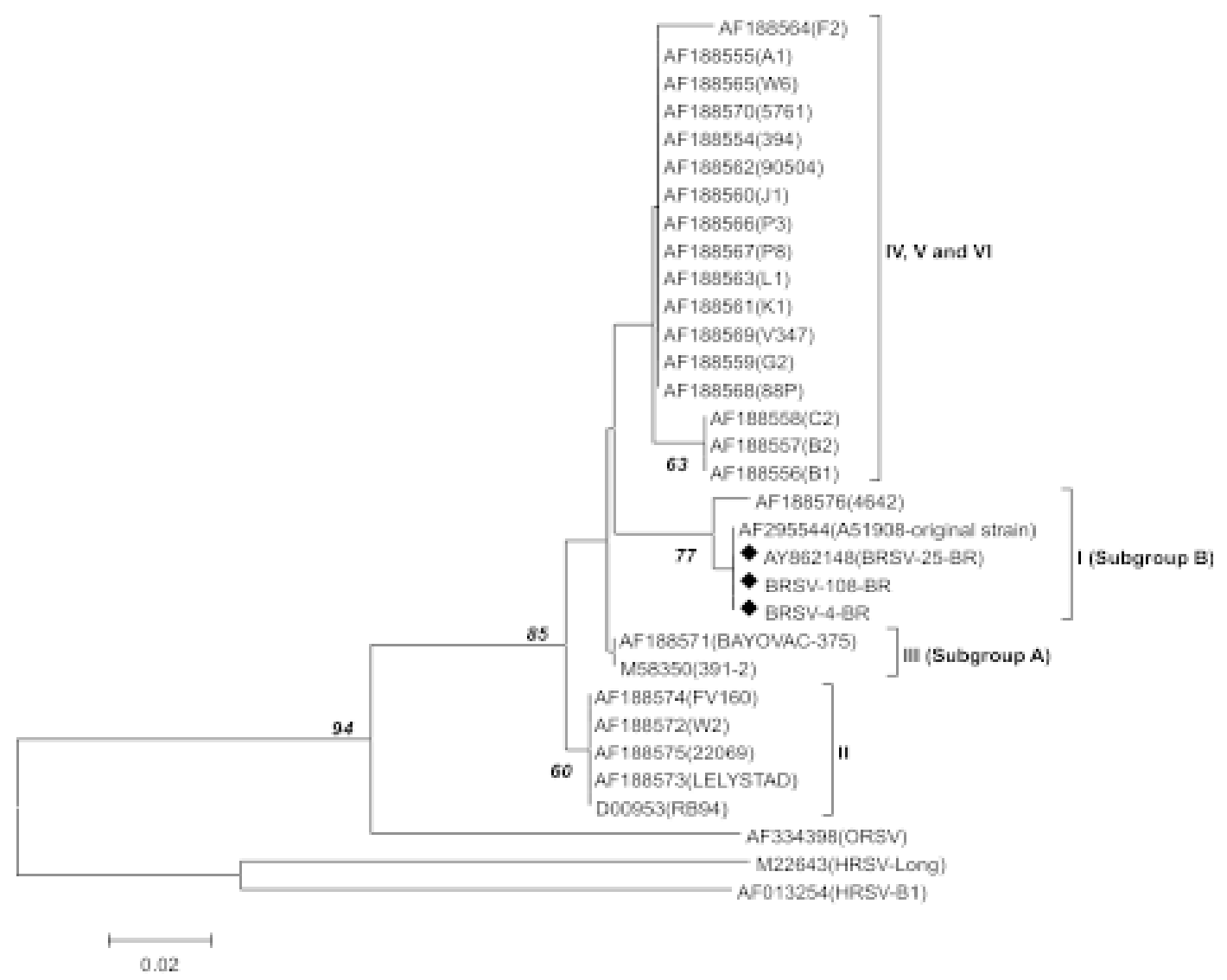

Figura 1. Dendrograma representando as relações evolutivas entre diferentes isolados do BRSV, com base em sequiências nucleotídicas do gene F. Os isolados brasileiros, incluídos na análise, estão assinalados com um losango. A reconstrução filogenética foi feita através do método de "Neighbor-joining", utilizando o parâmetro Kimura-2, e os valores de "bootstrap" estão representados numericamente nas interseções dos ramos. Os vírus ORSV e HRSV foram tomados como grupos externos.

151,161,162]. Trabalhos mais recentes demonstram a existência de seis grupos genômicos distintos, dada a presença de quatro genogrupos distintos dentre as amostras do subgrupo antigênico $A B[159,180]$. O isolamento de determinados subgrupos parece estar associado a questões temporais e de distribuição geográfica [159,160], sendo o subgrupo antigênico A encontrado nos Estados Unidos, Japão, Reino Unido e alguns países da Europa continental [56,93,117, 151,159]. O subgrupo AB está presente na Europa continental e Japão [85,159,162,180]; já o subgrupo B foi isolado no Reino Unido, em meados da década de 1970 [117,160], e reencontrado posteriormente apenas no Brasil, sendo que, dentre as poucas amostras isoladas até o presente momento neste país, todas foram classificadas no subgrupo B (Figura 1) $[6,12$, 149].

Em estudo realizado por nosso grupo, com base nas sequiências deduzidas de aminoácidos da proteína $\mathrm{G}$, a partir do seqüenciamento genômico, foi observada a presença de mutações na região central desta glicoproteína, presentes no isolado BRSV25-BR, afetando, entre outros resíduos de aminoácidos, duas cisteínas do nó de cisteínas existente nesse domínio da proteína [149]. Ao contrário de mutantes naturais de BRSV com substituições nestes mesmos aminoácidos, relatados em rebanhos vacinados [159], esse isolado é oriundo de um rebanho não vacinado [149]. A fixação desse mutante pode ter se dado pela pressão seletiva, exercida pela imunidade adquirida por estes animais apenas pelas reinfecções com BRSV, não sendo, portanto, necessária a vacinação, para a ocorrência desse fenômeno, como mencionado anteriormente. Tais eventos devem, de fato, estar envolvidos como estratégia de evolução dos vírus na natureza [160]. A análise estrutural, feita por meio de modelagem por homologia, não revelou alterações na possível estrutura tridimensional dessa região da 
proteína [149]. Será necessário realizar estudos mais aprofundados, utilizando o modelo experimental aprimorado no presente estudo, e estudos em bovinos, que possam elucidar se as funções atribuídas à proteína $\mathrm{G}$ foram alteradas no isolado BRSV-25-BR.

\section{EPIDEMIOLOGIA}

\section{Transmissão}

A transmissão do BRSV provavelmente ocorre por via aérea ou contato direto entre animais [101, 118]. A infecção primária pelo BRSV induz severa doença respiratória do trato inferior em bovinos suscetíveis, tanto jovens quanto adultos $[11,38,46]$. Dada a elevada taxa de prevalência observada por meio de sorologia, comparada com um diminuto número de casos clínicos, a maioria das infecções deve transcorrer de forma assintomática [92]. Em áreas endêmicas, a doença clínica é mais aparente nos animais jovens, à semelhança do que ocorre em crianças infectadas pelo HRSV. Após infecção natural pelo BRSV, a proteção contra reinfecções é de curta duração, e as reinfecções são comuns $[64,137,155,166]$. Em humanos, a severidade da enfermidade decresce após reinfecções consecutivas; em bovinos, sinais clínicos evidentes normalmente só são observados na primeira infecção $[96,164,166]$. A transmissão pela via transplacentária é bastante improvável [16].

\section{Situação no Brasil}

No Brasil, o BRSV foi isolado e caracterizado em 1995, a partir da secreção naso-traqueal de bezerros com sintomas respiratórios procedentes do Rio Grande do Sul [12]. Além de evidências sorológicas da infecção, a doença parece vir ocorrendo sistematicamente na região Sul do Brasil desde a década de 1980 [53], e já foram relatados casos nas regiões Sudeste e Norte do país $[6,7,38,126,149]$. Em nosso país, a infecção ocorre tanto em bovinos de corte quanto em animais destinados à produção leiteira, envolvendo animais alojados tanto em criações extensivas quanto em semi-extensivas. Os poucos relatos existentes de surtos de doença decorrente da infecção, em nosso país, podem dever-se a diferentes fatores: i) pouco conhecimento dos veterinários e produtores sobre os sinais clínicos e achados relevantes de necropsia associados à doença; ii) poucos laboratórios de diagnósticos com capacidade de realizar o diagnóstico; iii) labilidade do vírus, impedindo o diagnóstico em condições inadequadas de armazenamento e envio de amostras clínicas; iv) condições ambientais desfavoráveis à manifestação de sinais clínicos, na maior parte do território brasileiro, fazendo com que (ainda que tenham havido surtos em regiões quentes) a doença provocada pelo BRSV seja efetivamente de manifestação esporádica em nosso país.

\section{SINAIS CLÍNICOS E ACHADOS PATOLÓGICOS}

\section{Sinais clínicos}

Os sinais clínicos, após a infecção natural pelo BRSV, incluem apatia, anorexia, aumento de temperatura corporal $\left(>39,5^{\circ} \mathrm{C}\right)$, descargas nasais abundantes, tosse, taquipnéia, respiração bucal e abdominal, enfisema pulmonar e subcutâneo e morte $[7,14,28$, $38,55,168]$. Os animais, muitas vezes, apresentam dor ao toque da parede torácica e abdominal anterior. É comum encontrá-los em posição ortopnéica, com membros torácicos e pescoço estendido para a frente, respirando quase exclusivamente pela boca. Infecções bacterianas secundárias são freqüentes em surtos de BRSV, bem como o isolamento concomitante de outros vírus, formando o que constitui, no hemisfério norte, no chamado Complexo das Doenças Respiratórias dos Bovinos (CDRB) [42]. Diarréia também pode ser observada [38].

\section{Achados de necropsia}

Os achados macroscópicos são característicos de pneumonia intersticial multifocal (Figura 2) $[136,146]$. Enfisema intersticial e subpleural, distribuídos nas faces ventrais e craniais dos lobos pulmonares, estão presentes e acompanhados de espessamento dos septos interlobulares (Figura 3) [38]. As lesões microscópicas incluem a presença de células sinciciais com número variável de núcleos dispostos centralmente, as quais ocorrem em grande quantidade na parede dos alvéolos [38,136,146,152]. Enfisema alveolar, atelectasia, hipertrofia da camada muscular peribronquiolar em um quadro de severa bronquiolite $[8,38,92,102]$ e infiltração do tecido pulmonar com células mononucleares e eosinófilos [13, 109].

\section{Infecções experimentais em bovinos}

Tentativas de induzir os sinais clínicos e patológicos, relacionados à infecção pelo BRSV em bovinos, têm obtido diferentes graus de sucesso, com base no protocolo experimental adotado $[50,61,153]$. Alternativas como a inoculação intra-traqueal [7,22, 95,104], exposição dos animais à aerossolização lenta 


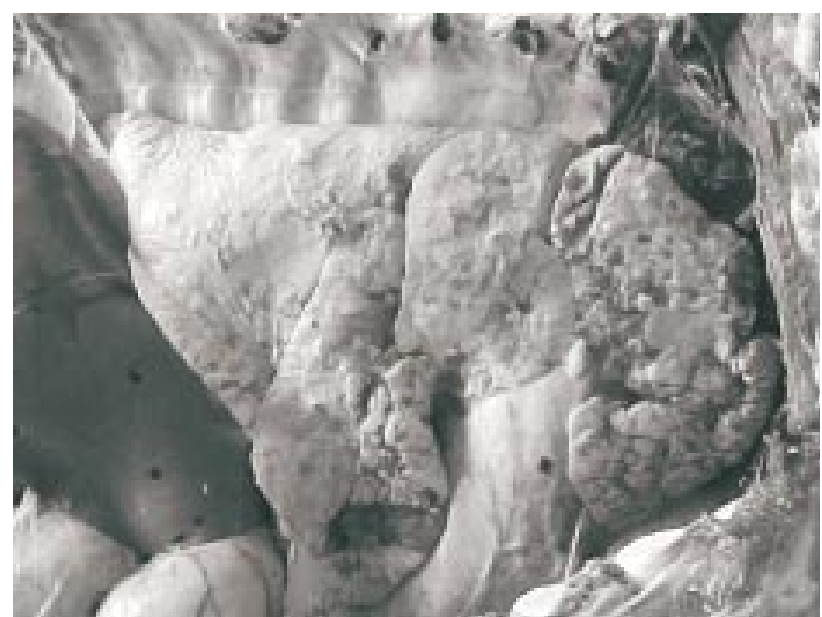

Figura 2. Pulmão direito de bovino de 1 ano de idade, notar as áreas de pneumonia hemorrágica nos lobos craniais e face ventral dos lobos pulmonares e as áreas de enfisema bolhoso distribuídas em todo o parênquima. A infecção pelo BRSV foi confirmada através da reação em cadeia da polimerase (PCR).

em câmara fechada, ou pré-imunização dos mesmos com vacinas inativadas pela formalina, ou, ainda, a co-administração de alérgenos do trato respiratório, foram relatados como meios de induzir sinais clínicos e lesões pulmonares mais evidentes em bovinos [10, 73,78].

\section{Infecções experimentais em outras espécies}

Dado o relativo grau de insucesso na inoculação experimental do BRSV em bovinos, tanto no estudo de diferentes estudos da imunopatogenia, bem como no teste de triagem de vacinas para o combate da infecção, seria de interesse a padronização de um protocolo de infecção do BRSV em um modelo experimental [111]. Ovinos já foram utilizados para tal fim, apresentando bons resultados no estudo de diferentes aspectos ligados à imunopatogenia da infecção pelo BRSV $[4,36,51,77,91,103,128,145]$. Com vistas a reduzir custos relacionados à experimentação, e utilizar animais com padrão genético conhecido, o uso de animais de laboratório, tais como camundongos, seria promissor, trazendo ainda a vantagem adicional de poder se utilizar linhagens isogênicas, conferindo maior repetibilidade e uniformidade aos resultados. Tal estratégia é amplamente utilizada no estudo das infecções pelo HRSV [41], porém os resultados quanto à reprodução da patologia, induzida pelo BRSV, não eram em roedores [5]. No entanto, experimentos anteriores, utilizando a inoculação de BRSV em camundongos da linhagem Balb/C demonstraram níveis moderados de replicação viral [5], na presença de

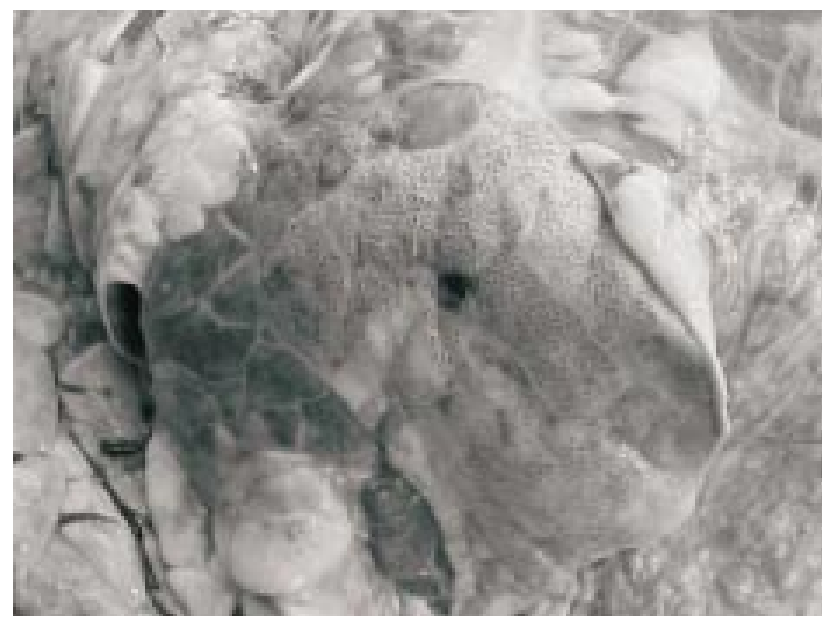

Figura 3. Enfisema subpleural adjacente a áreas de pneumonia hemorrágica no pulmão de bovino de 1 ano de idade. Notar o espessamento dos septos interlobulares. A infecção pelo BRSV foi confirmada através da reação em cadeia da polimerase (PCR).

pouco ou nenhum sinal clínico ou patológico evidente. Estes mesmos trabalhos sugeriram a possibilidade do uso de diferentes amostras virais, ou linhagens celulares, na preparação dos inóculos a serem utilizados nos experimentos, como meio de reproduzir melhor as características da infecção pelo BRSV em bovinos [92].

Recentemente, desenvolvemos estudos visando a obtenção de um modelo murino para o estudo da infecção pelo BRSV [150]. Ainda que o uso de pequenos ruminantes mostre-se promissor no estudo das infecções pelo BRSV, um modelo murino, baseado na determinação de linhagens mais suscetíveis à infecção viral, pode ser de grande interesse prático na pesquisa de diferentes aspectos relativos à infecção pelo BRSV [150]. Os animais da linhagem Balb/C revelaram permitir níveis mais elevados de replicação viral, todavia, os animais das linhagens C57BL6 e A/J demonstraram lesões histopatológicas evidentes [150]. Isto pode ser de grande interesse, especialmente na compreensão de mecanismos ligados à imunobiologia da infecção pelo BRSV, bem como em testes de triagem de vacinas e drogas terapêuticas. Um refinamento possível do modelo obtido seria a co-infecção dos animais com o BRSV, e bactérias comumente associadas nos casos clínicos CDRB nos rebanhos bovinos, como uma tentativa de aproximar ainda mais os resultados clínicos e de patogenia observados em camundongos daqueles notados no hospedeiro natural. Outra estratégia seria a pré-imunização 
dos animais com vacinas inativadas, utilizando formalina e alumínio como adjuvante, tal qual sugerido para bovinos, como uma tentativa de exacerbar ainda mais os sinais clínicos e patológicos observados $[10,74$, $75,178]$.

\section{IMUNIDADE E IMUNOPATOGENIA}

\section{Resposta imune protetora}

A proteína $\mathrm{F}$ é o principal alvo da resposta imune ao BRSV [54,115,139,181], sendo superior à proteína $\mathrm{G}$ no que tange à indução de resposta celular ou humoral $[9,26,116,133,143]$. A imunidade adquirida é importante na prevenção de sinais clínicos após reinfecções [90,141]. Anticorpos contra outras proteínas após infecções ou através de vacinação [47]. Ainda que, anticorpos maternos (AMs) estejam presentes no soro de bezerros nascidos de vacas previamente infectadas, a proteção conferida pelos AMs é controversa. Tais anticorpos não conferem proteção completa frente à infecção pelo BRSV [96,107,165], a incidência e severidade da doença clínica e dos achados patológicos são inversamente proporcionais ao título de AMs [44, 82,125]. Pôde-se também observar que os AMs causam um decréscimo na replicação do BRSV no parênquima pulmonar; a presença dos AMs suprime, ainda, a formação de resposta imune adquirida à infecção, o que pode prejudicar a eficácia da vacinação em animais jovens, especialmente utilizando vacinas vivas atenuadas [44].

\section{Imunopatogenia}

Do ponto de vista de direcionamento da resposta imune, o BRSV induz uma intensa resposta do tipo Th2 [59,73], com abundante secreção das citocinas IL-4 e IL-10, as quais provocam incremento na síntese de anticorpos, incluindo a classe IgE, e marcada eosinofilia [108,172]. Tal tipo de resposta é semelhante àquela induzida pelas infecções helmínticas, e deve explicar, em parte, o quadro de intensa bronquiolite evidenciado nas infecções pelo BRSV $[31,170$, 177].

\section{DIAGNÓSTICO}

\section{Ferramentas de diagnóstico}

O diagnóstico da infecção pelo BRSV é baseado na detecção de antígenos virais em amostras clínicas ou no inquérito sorológico dos rebanhos. O isolamento do vírus é difícil pela extrema labilidade do vírion $[12,70,84,129,173]$. As melhores alternativas são a imunofluorescência $[49,53]$ e técnicas moleculares que visem à amplificação de fragmentos específicos do genomado BRSV em amostras clínicas [7,25, 157,169,176]. A histopatologia, acompanhada ou não da realização de imunohistoquímica, também pode ser de grande auxílio no diagnóstico [38,126]. Para as análises sorológicas estão disponíveis testes de ELISA e protocolos envolvendo a soroneutralização $[43,65$, 167].

\section{Cultivo do vírus}

O BRSV pode replicar em uma grande variedade de células de cultivo primário, preparadas a partir de órgãos de bovinos e ovinos, sendo o efeito citopático característico a formação de sincícios (fusão de membranas de células adjacentes levando à formação de células multinucleadas). Muitas vezes, o efeito viral é discreto e de difícil visualização. Além dos cultivos derivados de tecidos extraídos de ruminantes, o vírus pode, ainda, ser adaptado a cultivos celulares de origem humana e de outras espécies [106]. Poucos trabalhos foram feitos quanto à determinação das características de multiplicação viral e títulos virais alcançados pelo BRSV em diferentes cultivos primários e de linhagem [106]. Em estudo realizado por nosso grupo, utilizando linhagens celulares e cultivos primários testados por nosso grupo, o BRSV só replicou em células de origem mamífera (CER, Vero, CRIB, MDBK, BEL), não sendo detectado após passagens em células de cultivo primário de fibroblasto de embrião de galinha (FEG) [148]. O conhecimento futuro do receptor celular, associado à adsorção do BRSV, provavelmente um glicosaminoglicano (GAG), será válido em explicar se as células de origem aviária não foram infectadas por BRSV, por diferenças nesse receptor entre aves e mamíferos, ou se o vírus não replica adequadamente em células aviárias por diferenças encontradas no microambiente celular.

\section{CONTROLE}

\section{Vacinas contra o BRSV}

Inúmeras vacinas inativadas e vivas estão disponíveis comercialmente para o controle das infecções pelo BRSV [29,34,45,174]. Estudos utilizando o desafio experimental e a campo têm levado a resultados desanimadores quanto à eficácia das vacinas $[29,34,45]$. 


\section{Implicações da diversidade antigênica para a} vacinação

A variabilidade antigência do BRSV também poderia teoricamente influir no sucesso da vacinação, pois ainda que exista imunidade sorológica cruzada, não se tem certeza sobre os graus de proteção cuzada entre os subgrupos. Com base nos dados de seqüências nucleotídicas dos genes G e F de BRSV obtidos a partir da amplificação dos respectivos fragmentos do genoma de isolados de BRSV brasileiros, nossa equipe vem buscando investigar as relações filogenéticas entre esses isolados e outros oriundos de várias partes do mundo. Claramente, tanto na caracterização dos mesmos, baseada tanto no gene $\mathrm{G}$ quanto no gene $\mathrm{F}$, tais isolados pertecem ao subgrupo B (grupo genômico I) do BRSV. Isso é relevante do ponto de vista epidemiológico, já que amostras do subgrupo B não circulam em outras partes do mundo já há 30 anos; tal fato sugere que a introdução do BRSV, em nosso território, deu-se em meados dos anos 1970, confirmando dados anteriores, obtidos a partir da pesquisa de antígenos de BRSV em tecidos pulmonares de animais com achados histopatológicos compatíveis, coletados na década de 1980 [6,149]. Outro aspecto a ressaltar é o fato das vacinas, comercialmente disponíveis no mercado brasileiro para o controle de infecções pelo BRSV, trazerem, em sua formulação, isolados pertencentes ao subgrupo A. Testes devem ser conduzidos futuramente visando determinar o grau de proteção clínica e, mais que isso, a diminuição na replicação, com a conseqüente redução na circulação de vírus nos rebanhos, através da imunização utilizando tais produtos. Relatos anteriores dão conta de que o uso de vacinas, cujos vírus vacinais apresentam baixos graus de identidade com os isolados circulantes na região, não só confere proteção clínica insatisfatória, como poderia levar ainda à seleção de mutantes de escape $[159,160]$. Esse fenômeno constituiria em um possível mecanismo de escape desses novos vírus ao sistema imune do hospedeiro, o que acontece quando a proteção dada pelas vacinas é apenas parcial [159].

\section{Desenvolvimento de novas vacinas}

Especificamente no caso do BRSV, onde um balanço adequado da resposta imune é necessário para proteger o animal dos efeitos clínicos da infecção, fazem-se necessárias mais pesquisas sobre diferentes adjuvantes para o uso em vacinas inativadas. $\mathrm{O}$ uso de diferentes adjuvantes em vacinas inativadas, buscando uma melhor resposta imune humoral e celular, assim como uma apropriada modulação dos ramos Th1 e Th2 do sistema imune, têm se revelado uma estratégia promissora no desenvolvimento de vacinas mais seguras e eficazes no combate a infecções pelo BRSV, bem como vacinas vetoriais e vacinas de DNA também vêm sendo testadas com relativo sucesso [17,18,48,112].

\section{CONCLUSÃO}

As infecções pelo BRSV, dadas as suas características únicas em relação à imunopatogenia da enfermidade, e à ubiqüidade da infecção, representam um desafio ao desenvolvimento de vacinas eficazes e seguras. De todo modo, são necessários esforços mais aprofundados, visando elucidar a real importância desta infecção no rebanho bovino brasileiro.

\section{REFERÊNCIAS}

1 Ahmadian G., Chambers P. \& Easton A.J. 1999. Detection and characterization of proteins encoded by the second ORF of the M2 gene of pneumoviruses. Journal of General Virology. 80: 2011-2016.

2 Alansari H. \& Potgieter L.N.D. 1994. Molecular-Cloning and Sequence-Analysis of the Phosphoprotein, Nucleocapsid Protein, Matrix Protein and 22k (M2) Protein of the Ovine Respiratory Syncytial Virus. Journal of General Virology. 75: 3597-3601.

3 Alansari H. \& Potgieter L.N.D. 1994. Nucleotide and Predicted Amino-Acid-Sequence Analysis of the Ovine Respiratory Syncytial Virus Nonstructural 1c and $1 \mathrm{~b}$ Genes and the Small Hydrophobic Protein Gene. Journal of General Virology. 75: 401-404.

4 Aldarraji A.M., Cutlip R.C. \& Lehmkuhl H.D. 1982. Experimental-Infection of Lambs with Bovine Respiratory Syncytial Virus and Pasteurella-Haemolytica-Immunofluorescent and Electron-Microscopic Studies. American Journal of Veterinary Research. 43: 230-235.

5 Almeida R.S., Domingues H.G., Coswig L.T., D'arce R.C.F., Carvalho R.F. \& Arns C.W. 2004. Detection of bovine respiratory syncytial virus in experimentally infected balb/c mice. Veterinary Research. 35: 189-197. 
6 Almeida R.S., Domingues H.G., Spilki F.R., Larsen L.E., Hagglund S., Belak S. \& Arns C.W. 2006. Circulation of bovine respiratory syncytial virus in Brazil. Veterinary Record. 158: 632-634.

7 Almeida R.S., Spilki F.R., Roehe P.M. \& Arns C.W. 2005. Detection of Brazilian bovine respiratory syncytial virus strain by a reverse transcriptase-nested-polymerase chain reaction in experimentally infected calves. Veterinary Microbiology. 105: 131-135.

8 Andrews G.A. \& Kennedy G.A. 1997. Respiratory diagnostic pathology. Veterinary Clinics of North America-Food Animal Practice. 13: 515-\&.

9 Antonis A.F.G., Claassen E.A.W., Hensen E.J., de Groot R.J., de Groot-Mijnes J.D.F., Schrijver R.S. \& Van der Most R.G. 2006. Kinetics of antiviral CD8 $\mathrm{T}$ cell responses during primary and post-vaccination secondary bovine respiratory syncytial virus infection. Vaccine. 24: 1551-1561.

10 Antonis A.F.G., Schrijver R.S., Daus F., Steverink P.J.G.M., Stockhofe N., Hensen E.J., Langedijk J.P.M. \& van der Most R. 2003. Vaccine-induced immunopathology during bovine respiratory syncytial virus infection: Exploring the parameters of pathogenesis. Journal of Virology. 77: 12067-12073.

11 Appel G. \& Heckert H.P. 1989. Interstitial Pneumonia (Aip) in Calves and Yearlings (Young Cattle) in Schleswig-Holstein in Association with an Infection by the Bovine Respiratory Syncytial Virus (Brsv). Deutsche Tierarztliche Wochenschrift. 96: 226-228.

12 Arns C.W., Campalans J., Costa S.C.B., Domingues H.G., D’Arce R.C.F. \& Almeida R.S. 2003. Characterization of bovine respiratory syncytial virus isolated in Brazil. Brazilian Journal of Medical and Biological Research. 36: $213-218$.

13 Ayroud M., Popp J.D., VanderKop M.A., Yost G.S., Haines D.M., Majak W., Karren D., Yanke L.J. \& McAllister T.A. 2000. Characterization of acute interstitial pneumonia in cattle in southern Alberta feedyards. Canadian Veterinary Journal-Revue Veterinaire Canadienne. 41: 547-554.

14 Baker J.C. 1986. Bovine Respiratory Syncytial Virus - Pathogenesis, Clinical Signs, Diagnosis, Treatment, and Prevention. Compendium on Continuing Education for the Practicing Veterinarian. 8: F31-\&.

15 Baker J.C. 1991. Human and Bovine Respiratory Syncytial Virus - Immunopathological Mechanisms. Veterinary Quarterly. 13: 47-59.

16 Baker J.C., Ciszewski D.K. \& Kirk J.H. 1989. Failure to Detect Antibody to Bovine Respiratory Syncytial Virus in Bovine Fetal Serum. Canadian Journal of Veterinary Research-Revue Canadienne De Recherche Veterinaire. 53: 103104.

17 Barr I.G. \& Mitchell G.F. 1996. ISCOMs (immunostimulating complexes): The first decade. Immunology and Cell Biology. 74: 8-25.

18 Barr I.G., Sjolander A. \& Cox J.C. 1998. ISCOMs and other saponin based adjuvants. Advanced Drug Delivery Reviews. 32: 247-271.

19 Becker Y. 2007. Past, present and future of RSV and PIV vaccines and anti-RSV antibodies for the protection of humans against RSV. Expert Opinion on Therapeutic Patents. 17: 941-953.

20 Bennett N., Ellis J., Bonville C., Rosenberg H. \& Domachowske J. 2007. Immunization strategies for the prevention of pneumovirus infections. Expert Review of Vaccines. 6: 169-182.

21 Bhella D., Ralph A., Murphy L.B. \& Yeo R.P. 2002. Significant differences in nucleocapsid morphology within the Paramyxoviridae. Journal of General Virology. 83: 1831-1839.

22 Bingham H.R., Morley P.S., Wittum T.E., Bray T.M., West K.H., Slemons R.D., Ellis J.A., Haines D.M., Levy M.A., Sarver C.F., Saville W.J.A. \& Cortese V.S. 1999. Synergistic effects of concurrent challenge with bovine respiratory syncytial virus and 3-methylindole in calves. American Journal of Veterinary Research. 60: 563-570.

23 Bossert B. \& Conzelmann K.K. 2002. Respiratory syncytial virus (RSV) nonstructural (NS) proteins as host range determinants: a chimeric bovine RSV with NS genes from human RSV is attenuated in interferon-competent bovine cells. Journal of Virology. 76: 4287-4293.

24 Bossert B., Marozin S. \& Conzelmann K.K. 2003. Nonstructural proteins NS1 and NS2 of bovine respiratory syncytial virus block activation of interferon regulatory factor 3. Journal of Virology. 77: 8661-8668.

25 Boxus M., Letellier C. \& Kerkhofs P. 2005. Real Time RT-PCR for the detection and quantitation of bovine respiratory syncytial virus. Journal of Virological Methods. 125: 125-130.

26 Brady R.P., Topliff C.L. \& Kelling C.L. 2004. In vitro expression of full-length and truncated bovine respiratory syncytial virus $\mathrm{G}$ proteins and their antibody responses in BALB/c mice. Vaccine. 22: 3762-3768.

27 Branigan P.J., Day N.D., Liu C.B., Gutshall L.L., Melero J.A., Sarisky R.T. \& Del Vecchio A.M. 2006. The cytoplasmic 
domain of the F protein of Human respiratory syncytial virus is not required for cell fusion. Journal of General Virology. 87: 395-398.

28 Brugerepicoux J. \& Cottereau P. 1987. Bovine Respiratory Syncytial Virus-Microbial and Clinical Aspects. Tierarztliche Umschau. 42: 440-\&.

29 Bryson D.G., Adair B.M., McNulty M.S., McAliskey M., Bradford H.E.L., Allan G.M., Evans R.T. \& Forster F. 1999. Studies on the efficacy of intranasal vaccination for the prevention of experimentally induced parainfluenza type 3 virus pneumonia in calves. Veterinary Record. 145: 33-39.

30 Bryson D.G., Mcconnell S., Mcaliskey M. \& Mcnulty M.S. 1991. Ultrastructural Features of Alveolar Lesions in Induced Respiratory Syncytial Virus Pneumonia of Calves. Veterinary Pathology. 28: 286-292.

31 Bryson D.G., Platten M.F., Mcconnell S. \& Mcnulty M.S. 1991. Ultrastructural Features of Lesions in Bronchiolar Epithelium in Induced Respiratory Syncytial Virus Pneumonia of Calves. Veterinary Pathology. 28: 293-299.

32 Buchholz U.J., Finke S. \& Conzelmann K.K. 1999. Generation of bovine respiratory syncytial virus (BRSV) from cDNA: BRSV NS2 is not essential for virus replication in tissue culture, and the human RSV leader region acts as a functional BRSV genome promoter. Journal of Virology. 73: 251-259.

33 Buchholz U.J., Granzow H., Schuldt K., Whitehead S.S., Murphy B.R. \& Collins P.L. 2000. Chimeric bovine respiratory syncytial virus with glycoprotein gene substitutions from human respiratory syncytial virus (HRSV): Effects on host range and evaluation as a live-attenuated HRSV vaccine. Journal of Virology. 74: 1187-1199.

34 Carmel D.K., Barao S.M. \& Douglass L.W. 1992. Effects of Vaccination against 18 Immunogens in Beef Replacement Heifers at Weaning. Journal of the American Veterinary Medical Association. 201: 587-590.

35 Cristina J., Yunus A.S., Rockemann D.D. \& Samal S.K. 1998. Genetic analysis of the G and $P$ genes in ungulate respiratory syncytial viruses by RNase A mismatch cleavage method. Veterinary Microbiology. 62: 185-192.

36 Cutlip R.C. \& Lehmkuhl H.D. 1979. Lesions in Lambs Experimentally Infected with Bovine Respiratory Syncytial Virus. American Journal of Veterinary Research. 40: 1479-1482.

37 Doreleijers J.F., Langedijk J.P.M., Hard K., Boelens R., Rullmann J.A.C., Schaaper W.M., vanOirschot J.T. \& Kaptein R. 1996. Solution structure of the immunodominant region of protein $\mathrm{G}$ of bovine respiratory syncytial virus. Biochemistry. 35: $14684-14688$.

38 Driemeier D., Gomes M.J.P., Moojen V., Arns C.W., Vogg G., Kessler L. \& daCosta U.M. 1997. Clinico-pathological aspects in the natural infection of Bovine Respiratory Syncytial Virus (BRSV) in extensive management of cattle in Rio Grande do Sul, Brazil. Pesquisa Veterinaria Brasileira. 17: 77-81.

39 Duncan R.B. \& Potgieter L.N.D. 1993. Antigenic Diversity of Respiratory Syncytial Viruses and Its Implication for Immunoprophylaxis in Ruminants. Veterinary Microbiology. 37: 319-341.

40 Dupuy L.C., Dobson S., Bitko V. \& Barik S. 1999. Casein kinase 2-mediated phosphorylation of respiratory syncytial virus phosphoprotein $\mathrm{P}$ is essential for the transcription elongation activity of the viral polymerase; Phosphorylation by casein kinase 1 occurs mainly at Ser(215) and is without effect. Journal of Virology. 73: 8384-8392.

41 Easton A.J., Domachowske J.B. \& Rosenberg H.F. 2004. Animal pneumoviruses: Molecular genetics and pathogenesis. Clinical Microbiology Reviews. 17: 390.

42 Ellis J.A. 2001. The immunology of the bovine respiratory disease complex. Veterinary Clinics of North America-Food Animal Practice. 17: 535.

43 Ellis J.A., Hassard L. \& Morley P.S. 1995. Development and Application of a Microneutralization Elisa for the Detection of Antibodies to Bovine Respiratory Syncytial Viruses. Journal of Veterinary Diagnostic Investigation. 7: 183-189.

44 Ellis J.A., Hassard L.E., Cortese V.S. \& Morley P.S. 1996. Effects of perinatal vaccination on humoral and cellular immune responses in cows and young calves. Journal of the American Veterinary Medical Association. 208: 393-400.

45 Ellis J.A., Hassard L.E. \& Morley P.S. 1995. Bovine Respiratory Syncytial Virus-Specific Immune-Responses in Calves after Inoculation with Commercially Available Vaccines. Journal of the American Veterinary Medical Association. 206: 354-361.

46 Ellis J.A., Philibert H., West K., Clark E., Martin K. \& Haines D. 1996. Fatal pneumonia in adult dairy cattle associated with active infection with bovine respiratory syncytial virus. Canadian Veterinary Journal-Revue Veterinaire Canadienne. 37: 103-105.

47 Ellis J.A., Russell H., Cavender J. \& Haven T.R. 1992. Bovine Respiratory Syncytial Virus-Specific Immune-Responses in Cattle Following Immunization with Modified-Live and Inactivated Vaccines-Analysis of the Specificity and Activity 
of Serum Antibodies. Veterinary Immunology and Immunopathology. 34: 35-45.

48 Ellis J.A., West K.H., Waldner C. \& Rhodes C. 2005. Efficacy of a saponin-adjuvanted inactivated respiratory syncytial virus vaccine in calves. Canadian Veterinary Journal-Revue Veterinaire Canadienne. 46: 155-162.

49 Elvander M. 1996. Severe respiratory disease in dairy cows caused by infection with bovine respiratory syncytial virus. Veterinary Record. 138: 101-105.

50 Elvander M., Baule C., Persson M., Egyed L., Ballagi-Pordany A., Belak S. \& Alenius S. 1998. An experimental study of a concurrent primary infection with bovine respiratory syncytial virus (BRSV) and bovine viral diarrhoea virus (BVDV) in calves. Acta Veterinaria Scandinavica. 39: 251-264.

51 Fach S.J., Meyerholz D.K., Gallup J.M., Ackermann M.R., Lehmkuhl H.D. \& Sacco R.E. 2007. Neonatal ovine pulmonary dendritic cells support bovine respiratory syncytial virus replication with enhanced interleukin (IL)-4 and IL-10 gene transcripts. Viral Immunology. 20: 119-130.

52 Feldman S.A., Audet S. \& Beeler J.A. 2000. The fusion glycoprotein of human respiratory syncytial virus facilitates virus attachment and infectivity via an interaction with cellular heparan sulfate. Journal of Virology. 74: 6442-6447.

53 Flores E.F., Weiblen R., Medeiros M., Botton S.A., Irigoyen L.F., Driemeier D., Schuch L.F. \& Moraes M. 2000. A retrospective search for bovine respiratory syncytial virus (BRSV) antigens in histological specimens by immunofluorescence and immunohistochemistry. Pesquisa Veterinaria Brasileira. 20: 139-143.

54 Fogg M.H., Parsons K.R., Thomas L.H. \& Taylor G. 2001. Identification of CD4(+) T cell epitopes on the fusion (F) and attachment $(G)$ proteins of bovine respiratory syncytial virus (BRSV). Vaccine. 19: 3226-3240.

55 Frappier E., Lucas C., Serrand S., Rolland G. \& Bataillon G. 1986. Bovine Respiratory Syncytial Virus Isolation in France - Clinical and Virological Studies. Recueil De Medecine Veterinaire. 162: 1189-1194.

56 Furze J., Wertz G., Lerch R. \& Taylor G. 1994. Antigenic Heterogeneity of the Attachment Protein of Bovine Respiratory Syncytial Virus. Journal of General Virology. 75: 363-370.

57 Furze J.M., Roberts S.R., Wertz G.W. \& Taylor G. 1997. Antigenically distinct G glycoproteins of BRSV strains share a high degree of genetic homogeneity. Virology. 231: 48-58.

58 Galinski M.S. 1991. Paramyxoviridae-Transcription and Replication. Advances in Virus Research. 39: 129-162.

59 Gershwin L.J., Berghaus L.J., Arnold K., Anderson M.L. \& Corbeil L.B. 2005. Immune mechanisms of pathogenetic synergy in concurrent bovine pulmonary infection with Haemophilus somnus and bovine respiratory syncytial virus. Veterinary Immunology and Immunopathology. 107: 119-130.

60 Gershwin L.J., Gunther R.A., Smith S., Boyle G.A. \& Friebertshauser K.E. 1994. Characterization of a Bovine Model for Studying the Immunological Responses to Respiratory Syncytial Virus-Infection. Faseb Journal. 8: A490-A490.

61 Gershwin L.J., Schelegle E.S., Gunther R.A., Anderson M.L., Woolums A.R., Larochelle D.R., Boyle G.A., Friebertshauser K.E. \& Singer R.S. 1998. A bovine model of vaccine enhanced respiratory syncytial virus pathophysiology. Vaccine. 16: 1225-1236.

62 Gotoh B., Komatsu T., Takeuchi K. \& Yokoo J. 2001. Paramyxovirus accessory proteins as interferon antagonists. Microbiology and Immunology. 45: 787-800.

63 Gould A.R. 1996. Comparison of the deduced matrix and fusion protein sequences of equine morbillivirus with cognate genes of the Paramyxoviridae. Virus Research. 43: 17-31.

64 Graham D.A., Foster J.C., Mawhinney K.A., Elvander M., Adair B.M. \& Merza M. 1999. Detection of IgM responses to bovine respiratory syncytial virus by indirect ELISA following experimental infection and reinfection of calves: abolition of false positive and false negative results by pre-treatment of sera with protein-G agarose. Veterinary Immunology and Immunopathology. 71: 41-51.

65 Hagglund S., Svensson C., Emanuelson U., Valarcher J.F. \& Alenius S. 2006. Dynamics of virus infections involved in the bovine respiratory disease complex in Swedish dairy herds. Veterinary Journal. 172: 320-328.

66 Haller A.A., MacPhail M., Mitiku M. \& Tang R.S. 2001. A single amino acid substitution in the viral polymerase creates a temperature-sensitive and attenuated recombinant bovine parainfluenza virus type 3. Virology. 288: 342-350.

67 Haller A.A., Miller T., Mitiku M. \& Coelingh K. 2000. Expression of the surface glycoproteins of human parainfluenza virus type 3 by bovine parainfluenza virus type 3, a novel attenuated virus vaccine vector. Journal of Virology. 74: 1162611635.

68 Hardy R.W. \& Wertz G.W. 2000. The Cys(3)-His(1) motif of the respiratory syncytial virus M2-1 protein is essential for protein function. Journal of Virology. 74: 5880-5885. 
69 Inaba Y. 1971. Structure of Bovine Respiratory Syncytial (Nomi) Virus. Japanese Journal of Veterinary Science. 33: 10-\&.

70 Inaba Y., Tanaka Y., Omori T. \& Matumoto M. 1970. Isolation of Bovine Respiratory Syncytial Virus. Japanese Journal of Experimental Medicine. 40: 473-\&.

71 Ito Y., Tanaka Y., Inaba Y. \& Omori T. 1973. Structure of Bovine Respiratory Syncytial Virus. Archiv Fur Die Gesamte Virusforschung. 40: 198-204.

72 Jordan I.K., Sutter B.A. \& McClure M.A. 2000. Molecular evolution of the Paramyxoviridae and Rhabdoviridae multipleprotein-encoding P gene. Molecular Biology and Evolution. 17: 75-86.

73 Kalina W.V., Anderson M.L. \& Gershwin L.J. 2006. Altemaria aerosol during a bovine respiratory syncytial virus infection alters the severity of subsequent re-infection and enhances IgE production. Comparative Immunology Microbiology and Infectious Diseases. 29: 138-156.

74 Kalina W.V., Wollums A.R., Berghaus R.D. \& Gershwin L.J. 2004. Formalin-inactivated bovine RSV vaccine enhances a Th2 mediated immune response in infected cattle. Vaccine. 22: 1465-1474.

75 Kalina W.V., Woolums A.R. \& Gershwin L.J. 2005. Formalin-inactivated bovine RSV vaccine influences antibody levels in bronchoalveolar lavage fluid and disease outcome in experimentally infected calves. Vaccine. 23: 4625-4630.

76 Karger A., Schmidt U. \& Buchholz U.J. 2001. Recombinant bovine respiratory syncytial virus with deletions of the G or SH genes: G and F proteins bind heparin. Journal of General Virology. 82: 631-640.

77 Keles I., Sharma A., Woldehiwet Z. \& Murray R.D. 1999. The effects of bovine respiratory syncytial on normal ovine lymphocyte responses to mitogens or antigens in vitro. Comparative Immunology Microbiology and Infectious Diseases. 22: 1-13.

78 Keles I., Woldehiwet Z. \& Murray R.D. 1998. Vaccination with glutaraldehyde-fixed bovine respiratory syncytial virus (BRSV)-infected cells stimulates a better immune response in lambs than vaccination with heat-inactivated cell-free BRSV. Vaccine. 16: 1172-1178.

79 Khattar S.K., Yunus A.S., Collins P.L. \& Samal S.K. 2000. Mutational analysis of the bovine respiratory syncytial virus nucleocapsid protein using a minigenome system: Mutations that affect encapsidation, RNA synthesis, and interaction with the phosphoprotein. Virology. 270: 215-228.

80 Khattar S.K., Yunus A.S., Collins P.L. \& Samal S.K. 2001. Deletion and substitution analysis defines regions and residues within the phosphoprotein of bovine respiratory syncytial virus that affect transcription, RNA replication, and interaction with the nucleoprotein. Virology. 285: 253-269.

81 Khattar S.K., Yunus A.S. \& Samal S.K. 2001. Mapping the domains on the phosphoprotein of bovine respiratory syncytial virus required for N-P and P-L interactions using a minigenome system. Journal of General Virology. 82: 775-779.

82 Kimman T.G., Zimmer G.M., Westenbrink F., Mars J. \& Vanleeuwen E. 1988. Epidemiological-Study of Bovine Respiratory Syncytial Virus-Infections in Calves - Influence of Maternal Antibodies on the Outcome of Disease. Veterinary Record. 123: 104-109.

83 Konig P., Giesow K., Schuldt K., Buchholz U.J. \& Keil G.M. 2004. A novel protein expression strategy using recombinant bovine respiratory syncytial virus (BRSV): modifications of the peptide sequence between the two furin cleavage sites of the BRSV fusion protein yield secreted proteins, but affect processing and function of the BRSV fusion protein. Journal of General Virology. 85: 1815-1824.

84 Kovarcik K. 1999. Isolation of bovine respiratory syncytial virus during an outbreak of acute respiratory disease in calves. Veterinarni Medicina. 44: 121-127.

85 Kovarcik K. \& Valentova V. 2004. Bovine respiratory syncytial virus strains currently circulating in the Czech Republic are most closely related to Danish strains from 1995. Acta Virologica. 48: 57-62.

86 Krishnamurthy S. \& Samal S.K. 1998. Identification of regions of bovine respiratory syncytial virus N protein required for binding to P protein and self-assembly. Journal of General Virology. 79: 1399-1403.

87 Kuhnle G., Heinze A., Schmitt J., Giesow K., Taylor G., Morrison I., Rijsewijk F.A.M., van Oirschot J.T. \& Keil G.M. 1998. The class II membrane glycoprotein $\mathrm{G}$ of bovine respiratory syncytial virus, expressed from a synthetic open reading frame, is incorporated into virions of recombinant bovine herpesvirus 1. Journal of Virology. 72: 3804-3811.

88 Langedijk J.P.M., Daus F.J. \& VanOirschot J.T. 1997. Sequence and structure alignment of Paramyxoviridae attachment proteins and discovery of enzymatic activity for a morbillivirus hemagglutinin. Journal of Virology. 71: 6155-6167.

89 Langedijk J.P.M., Meloen R.H., Taylor G., Furze J.M. \& vanOirschot J.T. 1997. Antigenic structure of the central conserved region of protein G of bovine respiratory syncytial virus. Journal of Virology. 71: 4055-4061.

90 Langedijk J.P.M., Meloen R.H. \& van Oirschot J.T. 1998. Identification of a conserved neutralization site in the first 
heptad repeat of the fusion protein of respiratory syncytial virus. Archives of Virology. 143: 313-320.

91 Lapin C.D., Hiatt P.W., Langston C., Mason E. \& Piedra P.T. 1993. A Lamb Model for Human Respiratory Syncytial Virus-Infection. Pediatric Pulmonology. 15: 151-156.

92 Larsen L.E. 2000. Bovine respiratory syncytial virus (BRSV): A review. Acta Veterinaria Scandinavica. 41 : 1-21.

93 Larsen L.E., Tjornehoj K. \& Viuff B. 2000. Extensive sequence divergence among bovine respiratory syncytial viruses isolated during recurrent outbreaks in closed herds. Journal of Clinical Microbiology. 38: 4222-4227.

94 Larsen L.E., Uttenthal A., Arctander P., Tjornehoj K., Viuff B., Rontved C., Ronsholt L., Alexandersen S. \& BlixenkroneMoller M. 1998. Serological and genetic characterisation of bovine respiratory syncytial virus (BRSV) indicates that Danish isolates belong to the intermediate subgroup: no evidence of a selective effect on the variability of $\mathrm{G}$ protein nucleotide sequence by prior cell culture adaption and passages in cell culture or calves. Veterinary Microbiology. 62: 265-279.

95 Leblanc P.H., Baker J.C., Gray P.R., Robinson N.E. \& Derksen F.J. 1991. Effects of Bovine Respiratory Syncytial Virus on Airway Function in Neonatal Calves. American Journal of Veterinary Research. 52: 1401-1406.

96 Letesson J.J. 2003. Compared immunology of human and bovine RS virus. Point Veterinaire. 34: 26.

97 Mallipeddi S.K., Lupiani B. \& Samal S.K. 1996. Mapping the domains on the phosphoprotein of bovine respiratory syncytial virus required for N-P interaction using a two-hybrid system. Journal of General Virology. 77: 1019-1023.

98 Mallipeddi S.K. \& Samal S.K. 1993. Analysis of the Ovine Respiratory Syncytial Virus (Rsv) G-Glycoprotein Gene Defines a Subgroup of Ungulate Rsv. Journal of General Virology. 74: 2787-2791.

99 Mallipeddi S.K. \& Samal S.K. 1993. Sequence Variability of the Glycoprotein Gene of Bovine Respiratory Syncytial Virus. Journal of General Virology. 74: 2001-2004.

100 Marriott A.C. \& Easton A.J. 1999. Reverse genetics of the paramyxoviridae. Advances in Virus Research, v. 53. 53: 321340.

101 Mars M.H., Bruschke C.J.M. \& van Oirschot J.T. 1999. Airborne transmission of BHV1, BRSV, and BVDV among cattle is possible under experimental conditions. Veterinary Microbiology. 66: 197-207.

102 Martinez M.S., Masot A.J., Gazquez A., Tovar M. \& Redondo E. 1995. Spontaneous Brsv Infection in Kids - Pathological Observations. Archivos De Medicina Veterinaria. 27: 91-99.

103 Masot A.J., Duran M.E., Roncero V., GazquezA. \& Redondo E. 1992. Experimental Bovine Respiratory Syncytial VirusInfection in Lambs - Ultrastructural-Study of Lung. Revue De Medecine Veterinaire. 143: 57-63.

104 Masot A.J., Gomeztejedor C., Tovar I., Gazquez A. \& Redondo E. 1993. Location of Bovine Respiratory Syncytial Virus-Antigens in the Lung of Experimentally-Infected Lambs - Comparative-Study Using Indirect Fluorescent-Antibody Test, Avidin-Biotin-Peroxidase Complex and Transmission Electron-Microscopy. European Journal of Histochemistry. 37: 75-82.

105 Matheise J.P., Walravens K., Collard A., Coppe P. \& Letesson J.J. 1995. Antigenic Analysis of the F-Protein of the Bovine Respiratory Syncytial Virus - Identification of 2 Distinct Antigenic Sites Involved in Fusion Inhibition. Archives of Virology. 140: 993-1005.

106 Matumoto M., Inaba Y., Kurogi H., Sato K., Omori T., Goto Y. \& Hirose O. 1974. Bovine Respiratory Syncytial Virus - Host Range in Laboratory-Animals and Cell-Cultures. Archiv Fur Die Gesamte Virusforschung. 44: $280-290$.

107 Mawhinney I.C. \& Burrows M.R. 2005. Protection against bovine respiratory syncytial virus challenge following a single dose of vaccine in young calves with maternal antibody. Veterinary Record. 156: 139-143.

108 McInnes E., Collins R.A. \& Taylor G. 1998. Cytokine expression in pulmonary and peripheral blood mononuclear cells from calves infected with bovine respiratory syncytial virus. Research in Veterinary Science. 64: 163-166.

109 Mcinnes E., Sopp P., Howard C.J. \& Taylor G. 1999. Phenotypic analysis of local cellular responses in calves infected with bovine respiratory syncytial virus. Immunology. 96: 396-403.

110 Meehan J.T., Cutlip R.C. \& Lehmkuhl H.D. 1989. Evaluation of Ethylenediaminetetraacetic Acid, Tetrasodium Salt Dihydrate (Edta)-Tween 20 Treatment Versus Protease Digestion of Formalin-Fixed Tissue-Sections for Detection of Bovine Respiratory Syncytial Virus-Antigen in Infected Ovine Lung. Veterinary Pathology. 26: 322-325.

111 Meyer G., Deplanche M. \& Schelcher F. 2008. Human and bovine respiratory syncytial virus vaccine research and development. Comparative Immunology Microbiology and Infectious Diseases. 31: 191-225.

112 Morein B., Hu K.F. \& Abusugra I. 2004. Current status and potential application of ISCOMs in veterinary medicine. Advanced Drug Delivery Reviews. 56: 1367-1382.

113 Moussa A. 1994. Assembly of Enveloped Respiratory Syncytial Virus-Particles within the Cytoplasm of Infected Vero 
Cells. Archives of Virology. 134: 205-211.

114 Nagai Y. \& Kato A. 2004. Accessory genes of the Paramyxoviridae, a large family of nonsegmented negative-strand RNA viruses, as a focus of active investigation by reverse genetics. Biology of Negative Strand Rna Viruses: The Power of Reverse Genetics. 283: 197-248.

115 Naval J., Pinol J., Rebordosa X., SerraHartmann X., PerezPons J.A. \& Querol E. 1997. Expression in Escherichia coli and purification of soluble forms of the F protein of bovine respiratory syncytial virus. Protein Expression and Purification. 9: 288-294.

116 Nelson L.D., Kelling C.L. \& Anderson G.A. 1992. Antibody-Response of Calves to Immunoaffinity-Purified Bovine Respiratory Syncytial Virus Vp70 after Vaccination and Challenge Exposure. American Journal of Veterinary Research. 53: $1315-1321$.

117 Nettleton P.F., Gilray J.A., Caldow G., Gidlow J.R., Durkovic B. \& Vilcek S. 2003. Recent isolates of Bovine respiratory syncytial virus from Britain are more closely related to isolates from USA than to earlier British and current mainland European isolates. Journal of Veterinary Medicine Series B-Infectious Diseases and Veterinary Public Health. 50: 196199.

118 Norstrom M., Pfeiffer D.U. \& Jarp J. 2000. A space-time cluster investigation of an outbreak of acute respiratory disease in Norwegian cattle herds. Preventive Veterinary Medicine. 47: 107-119.

119 Oberst R.D., Hays M.P., Hennessy K.J., Stine L.C., Evermann J.F. \& Kelling C.L. 1993. Identifying Bovine Respiratory Syncytial Virus by Reverse Transcription-Polymerase Chain-Reaction and Oligonucleotide Hybridizations. Journal of Clinical Microbiology. 31: 1237-1240.

120 Paccaud M.F. \& Jacquier C. 1970. A Respiratory Syncytial Virus of Bovine Origin. Archiv Fur Die Gesamte Virusforschung. 30: $327-\&$.

121 Pastey M.K. \& Samal S.K. 1993. Structure and Sequence Comparison of Bovine Respiratory Syncytial Virus Fusion Protein. Virus Research. 29: 195-202.

122 Pastey M.K. \& Samal S.K. 1995. Nucleotide-Sequence Analysis of the Nonstructural Ns1 (1c) and Ns2 (1b) Protein Genes of Bovine Respiratory Syncytial Virus. Journal of General Virology. 76: 193-197.

123 Pastey M.K. \& Samal S.K. 1997. Analysis of bovine respiratory syncytial virus envelope glycoproteins in cell fusion. Journal of General Virology. 78: 1885-1889.

124 Pastey M.K. \& Samal S.K. 1998. Baculovirus expression of the fusion protein gene of bovine respiratory syncytial virus and utility of the recombinant protein in a diagnostic enzyme immunoassay. Journal of Clinical Microbiology. 36: $1105-1108$.

125 Patel J.R. \& Didlick S.A. 2004. Evaluation of efficacy of an inactivated vaccine against bovine respiratory syncytial virus in calves with maternal antibodies. American Journal of Veterinary Research. 65: 417-421.

126 Peixoto P.V., Mota R.A., Brito M.F., Corbellini L.G., Driemeier D. \& de Souza M.I. 2000. Spontaneous BRSV infection in cattle of the state of Alagoas, Brazil. Pesquisa Veterinária Brasileira. 20: 171-175.

127 Pomeroy L.W., Bjornstad O.N. \& Holmes E.C. 2008. The evolutionary and epidemiological dynamics of the paramyxoviridae. Journal of Molecular Evolution. 66: 98-106.

128 Poonia B. \& Sharma A.K. 1998. Modulation of lympho-proliferative responses of ovine peripheral blood mononuclear cells by Mycoplasma mycoides ssp. mycoides (LC type). Veterinary Immunology and Immunopathology. 64: 323-335.

129 Pospisil Z., Mensik J. \& Valicek L. 1978. Isolation and Identification of a Bovine Respiratory Syncytial Virus in Czechoslovakia. Acta Veterinaria Brno. 47: 79-\&.

130 Prozzi D., Walravens K., Langedijk J.P.M., Daus F., Kramps A. \& Letesson J.J. 1997. Antigenic and molecular analyses of the variability of bovine respiratory syncytial virus G glycoprotein. Journal of General Virology. 78: 359-366.

131 Samal S.K. \& Pastey M.K. 1997. Role of envelope glycoproteins of bovine respiratory syncytial virus in cell fusion. Indian Journal of Biochemistry \& Biophysics. 34: 181-185.

132 Samal S.K. \& Zamora M. 1991. Nucleotide-Sequence Analysis of a Matrix and Small Hydrophobic Protein Dicistronic Messenger-Rna of Bovine Respiratory Syncytial Virus Demonstrates Extensive Sequence Divergence of the Small Hydrophobic Protein from That of Human Respiratory Syncytial Virus. Journal of General Virology. 72: 1715-1720.

133Sandbulte M.R. \& Roth J.A. 2002. T-cell populations responsive to bovine respiratory syncytial virus in seronegative calves. Veterinary Immunology and Immunopathology. 84: 111-123.

134 Schlender J., Bossert B., Buchholz U. \& Conzelmann K.K. 2000. Bovine respirator syncytial virus nonstructural proteins NS1 and NS2 cooperatively antagonize alpha/beta interferon-induced antiviral response. Journal of Virology. 74: 82348242 . 
135Schlender J., Zimmer G., Herrler G. \& Conzelmann K.K. 2003. Respiratory syncytial virus (RSV) fusion protein subunit F2, not attachment protein G, determines the specificity of RSV infection. Journal of Virology. 77: 4609-4616.

136Schreiber P., Matheise J.P., Dessy F., Heimann M., Letesson J.J., Coppe P. \& Collard A. 2000. High mortality rate associated with bovine respiratory syncytial virus (BRSV) infection in Belgian White Blue calves previously vaccinated with an inactivated BRSV vaccine. Journal of Veterinary Medicine Series B-Infectious Diseases and Veterinary Public Health. 47: 535-550.

137 Schrijver R.S. 1998. Immunobiology of bovine respiratory syncytial virus infections. Tijdschrift Voor Diergeneeskunde. 123: 658-662.

138 Schrijver R.S., Daus F., Kramps J.A., Langedijk J.P.M., Buijs R., Middel W.G.J., Taylor G., Furze J., Huyben M.W.C. \& vanOirschot J.T. 1996. Subgrouping of bovine respiratory syncytial virus strains detected in lung tissue. Veterinary Microbiology. 53: 253-260.

139 Schrijver R.S., Hensen E.J., Langedijk J.P.M., Daus F., Middel W.G.J., Kramps J.A. \& vanOirschot J.T. 1997. Antibody responses against epitopes on the F protein of bovine respiratory syncytial virus differ in infected or vaccinated cattle. Archives of Virology. 142: 2195-2210.

140 Schrijver R.S., Langedijk J.P.M., Middel W.G.J., Kramps J.A., Rijsewijk F.A.M. \& van Oirschot J.T. 1998. A bovine respiratory syncytial virus strain with mutations in subgroup-specific antigenic domains of the $G$ protein induces partial heterologous protection in cattle. Veterinary Microbiology. 63: 159-175.

141 Schrijver R.S., Langedijk J.P.M., VanderPoel W.H.M., Middel W.G.J., Kramps J.A. \& VanOirschot J.T. 1996. Antibody responses against the $\mathrm{G}$ and $\mathrm{F}$ proteins of bovine respiratory syncytial virus after experimental and natural infections. Clinical and Diagnostic Laboratory Immunology. 3: 500-506.

142 Shadomy S.V., Baker J.C. \& Mufson M.A. 1997. Phosphoprotein profile analysis of ruminant respiratory syncytial virus isolates. American Journal of Veterinary Research. 58: 478-481.

143 Sharma A.K. \& Woldehiwet Z. 1996. Antigens of bovine respiratory syncytial virus in peripheral blood lymphocytes of experimentally infected lambs. Veterinary Immunology and Immunopathology. 50: 93-104.

144 Sharma A.K., Woldehiwet Z., Walrevens K. \& Letteson J. 1996. Immune responses of lambs to the fusion (F) glycoprotein of bovine respiratory syncytial virus expressed on insect cells infected with a recombinant baculovirus. Vaccine. 14: 773779.

145Sharma R. \& Woldehiwet Z. 1992. Reinfection of Lambs with Bovine Respiratory Syncytial Virus. Research in Veterinary Science. 52: 72-77.

146Sorden S.D., Kerr R.W. \& Janzen E.D. 2000. Interstitial pneumonia in feedlot cattle: concurrent lesions and lack of immunohistochemical evidence for bovine respiratory syncytial virus infection. Journal of Veterinary Diagnostic Investigation. 12: 510-517.

147 Spann K.M., Tran K.C., Chi B., Rabin R.L. \& Collins P.L. 2004. Suppression of the induction of alpha, beta, and gamma interferons by the NS1 and NS2 proteins of human respiratory syncytial virus in human epithelial cells and macrophages. Journal of Virology. 78: 4363-4369.

148Spilki F.R., Almeida R.S., Campalans J. \& Arns C.W. 2006. Susceptibility of different cell lines to infection with bovine respiratory syncytial virus. Journal of Virological Methods. 131: 130-133.

149Spilki F.R., Almeida R.S., Domingues H.G., D’Arce R.C.F., Ferreira H.L., Campalans J., Costa S.C.B. \& Arns C.W. 2006. Phylogenetic relationships of Brazilian bovine respiratory syncytial virus isolates and molecular homology modeling of attachment glycoprotein. Virus Research. 116: 30-37.

150 Spilki F.R., Almeida R.S., Ferreira H.L., Gameiro J., Verinaud L. \& Arns C.W. 2006. Effects of experimental inoculation of bovine respiratory syncytial virus in different inbred mice lineages: Establishment of a murine model for BRSV infection. Veterinary Microbiology. 118: 161-168.

151 Stine L.C., Hoppe D.K., Clayton C.L. \& Kelling C.L. 1997. Sequence conservation in the attachment glycoprotein and antigenic diversity among bovine respiratory syncytial virus isolates. Veterinary Microbiology. 54: 201-221.

152 Thomas L.H., Cook R.S., Howard C.J., Gaddum R.M. \& Taylor G. 1996. Influence of selective T-lymphocyte depletion on the lung pathology of gnotobiotic calves and the distribution of different T-lymphocyte subsets following challenge with bovine respiratory syncytial virus. Research in Veterinary Science. 61: 38-44.

153 Tjornehoj K., Uttenthal A., Viuff B., Larsen L.E., Rontved C. \& Ronsholt L. 2003. An experimental infection model for reproduction of calf pneumonia with bovine respiratory syncytial virus (BRSV) based on one combined exposure of 
calves. Research in Veterinary Science. 74: 55-65.

154 Trudel M., Nadon F., Simard C., Belanger F., Alain R., Seguin C. \& Lussier G. 1989. Comparison of Caprine, Human and Bovine Strains of Respiratory Syncytial Virus. Archives of Virology. 107: 141-149.

155 Uttenthal A., Larsen L.E., Philipsen J.S., Tjornehoj K., Viuff B., Nielsen K.H. \& Nielsen T.K. 2000. Antibody dynamics in BRSV-infected Danish dairy herds as determined by isotype-specific immunoglobulins. Veterinary Microbiology. 76: 329-341.

156 Vainionpää R., Marusyk R. \& Salmi A. 1989. The Paramyxoviridae - Aspects of Molecular-Structure, Pathogenesis, and Immunity. Advances in Virus Research. 37: 211-242.

157 Valarcher J.F., Bourhy H., Gelfi J. \& Schelcher F. 1999. Evaluation of a nested reverse transcription-PCR assay based on the nucleoprotein gene for diagnosis of spontaneous and experimental bovine respiratory syncytial virus infections. Journal of Clinical Microbiology. 37: 1858-1862.

158 Valarcher J.F., Furze J., Wyld S.G., Cook R., Zimmer G., Herrler G. \& Taylor G. 2006. Bovine respiratory syncytial virus lacking the virokinin or with a mutation in furin cleavage site $\mathrm{RA}(\mathrm{R} / \mathrm{K}) \mathrm{R}-109$ induces less pulmonary inflammation without impeding the induction of protective immunity in calves. Journal of General Virology. 87: 1659-1667.

159 Valarcher J.F., Schelcher F. \& Bourhy H. 2000. Evolution of bovine respiratory syncytial virus. Journal of Virology. 74 : 10714-10728.

160 Valarcher J.F. \& Taylor G. 2007. Bovine respiratory syncytial virus infection. Veterinary Research. 38: 153-180.

161 Valentova V. 2003. The antigenic and genetic variability of bovine respiratory syncytial virus with emphasis on the $G$ protein. Veterinarni Medicina. 48: 254-266.

162 Valentova V., Antonis A.F.G. \& Kovarcik K. 2005. Restriction enzyme analysis of RT-PCR amplicons as a rapid method for detection of genetic diversity among bovine respiratory syncytial virus isolates. Veterinary Microbiology. 108: 1-12.

163 Van der Poel W.H.M., Brand A., Kramps J.A. \& Van Oirschot J.T. 1994. Respiratory Syncytial Virus-Infections in Human-Beings and in Cattle. Journal of Infection. 29: 215-228.

164 Van der Poel W.H.M., Kramps J.A., Middel W.G.J., Van Oirschot J.T. \& Brand A. 1993. Dynamics of Bovine Respiratory Syncytial Virus-Infections - a Longitudinal Epidemiologic-Study in Dairy Herds. Archives of Virology. 133: 309-321.

165 Van der Poel W.H.M., Middel W.G.J. \& Schukken Y.H. 1999. Antibody titer against bovine respiratory syncytial virus in colostrum-fed dairy calves born in various seasons. American Journal of Veterinary Research. 60: 1098-1101.

166 Van der Poel W.H.M., Mourits M.C.M., Nielen M., Frankena K., Van Oirschot J.T. \& Schukken Y.H. 1995. Bovine Respiratory Syncytial Virus Reinfections and Decreased Milk-Yield in Dairy-Cattle. Veterinary Quarterly. 17: 77-81.

167 Van Nieuwstadt A.P. \& Verhoeff J. 1983. Serology for Diagnosis and Epizootiological Studies of Bovine Respiratory Syncytial Virus-Infections. Research in Veterinary Science. 35: 153-159.

168 Verhoeff J., Van der Ban M. \& Van Nieuwstadt A.P.K.M.I. 1984. Bovine Respiratory Syncytial Virus-Infections in Young Dairy-Cattle - Clinical and Hematological Findings. Veterinary Record. 114: 9-12.

169 Vilcek S., Elvander M., Ballagipordany A. \& Belak S. 1994. Development of Nested Pcr Assays for Detection of Bovine Respiratory Syncytial Virus in Clinical-Samples (v. 32, p. 2226, 1994). Journal of Clinical Microbiology. 32: $2887-2887$.

170 Viuff B., Uttenthal A., Tegtmeier C. \& Alexandersen S. 1996. Sites of replication of bovine respiratory syncytial virus in naturally infected calves as determined by in situ hybridization. Veterinary Pathology. 33: 383-390.

171 Walravens K., Kettmann R., Collard A., Coppe P. \& Burny A. 1990. Sequence Comparison between the Fusion Protein of Human and Bovine Respiratory Syncytial Viruses. Journal of General Virology. 71: 3009-3014.

172 Werling D., Collins R.A., Taylor G. \& Howard C.J. 2002. Cytokine responses of bovine dendritic cells and T cells following exposure to live or inactivated bovine respiratory syncytial virus. Journal of Leukocyte Biology. 72: $297-$ 304.

173 West K., Bogdan J., Hamel A., Nayar G., Morley P.S., Haines D.M. \& Ellis J.A. 1998. A comparison of diagnostic methods for the detection of bovine respiratory syncytial virus in experimental clinical specimens. Canadian Journal of Veterinary Research-Revue Canadienne De Recherche Veterinaire. 62: 245-250.

174 West K. \& Ellis J. 1997. Functional analysis of antibody responses of feedlot cattle to bovine respiratory syncytial virus following vaccination with mixed vaccines. Canadian Journal of Veterinary Research-Revue Canadienne De Recherche Veterinaire. 61: 28-33.

175 Westover K.M. \& Hughes A.L. 2001. Molecular evolution of viral fusion and matrix protein genes and phylogenetic relationships among the Paramyxoviridae. Molecular Phylogenetics and Evolution. 21: 128-134. 
176 Willoughby K., Thomson K., Maley M., Gilray J., Scholes S., Howie F., Caldow G. \& Nettleton P.F. 2008. Development of a real time reverse transcriptase polymerase chain reaction for the detection of bovine respiratory syncytial virus in clinical samples and its comparison with immunohistochemistry and immunofluorescence antibody testing. Veterinary Microbiology. 126: 264-270.

177 Woolums A.R., Anderson M.L., Gunther R.A., Schelegle E.S., LaRochelle D.R., Singer R.S., Boyle G.A., Friebertshauser K.E. \& Gershwin L.J. 1999. Evaluation of severe disease induced by aerosol inoculation of calves with bovine respiratory syncytial virus. American Journal of Veterinary Research. 60: 473-480.

178 Woolums A.R., Singer R.S., Boyle G.A. \& Gershwin L.J. 1999. Interferon gamma production during bovine respiratory syncytial virus (BRSV) infection is diminished in calves vaccinated with formalin-inactivated BRSV. Vaccine. 17: 12931297.

179 Wright C., Oliver K.C., Fenwick F.I., Smith N.M. \& Toms G.L. 1997. A monoclonal antibody pool for routine immunohistochemical detection of human respiratory syncytial virus antigens in formalin-fixed, paraffin-embedded tissue. Journal of Pathology. 182: 238-244.

180 Yaegashi G., Seimiya Y.M., Seki Y. \& Tsunemitsu H. 2005. Genetic and antigenic analyses of bovine respiratory syncytial virus detected in Japan. Journal of Veterinary Medical Science. 67: 145-150.

181 Yancey R.J. 1993. Recent Advances in Bovine Vaccine Technology. Journal of Dairy Science. 76: 2418-2436.

182 Young D.F., Didcock L., Goodbourn S. \& Randall R.E. 2000. Paramyxoviridae use distinct virus-specific mechanisms to circumvent the interferon response. Virology. 269: 383-390.

183 Yunus A.S., Collins P.L. \& Samal S.K. 1998. Sequence analysis of a functional polymerase (L) gene of bovine respiratory syncytial virus: determination of minimal trans-acting requirements for RNA replication. Journal of General Virology. 79: 2231-2238.

184 Yunus A.S., Khattar S.K., Collins P.L. \& Samal S.K. 2001. Rescue of bovine respiratory syncytial virus from cloned cDNA: Entire genome sequence of BRSV strain A51908. Virus Genes. 23: 157-164.

185 Yunus A.S., Krishnamurthy S., Pastey M.K., Huang Z., Khattar S.K., Collins P.L. \& Samal S.K. 1999. Rescue of a bovine respiratory syncytial virus genomic RNA analog by bovine, human and ovine respiratory syncytial viruses confirms the "functional integrity" and "cross-recognition" of BRSV cis-acting elements by HRSV and ORSV. Archives of Virology. 144: 1977-1990.

186Zamora M. \& Samal S.K. 1992. Gene Junction Sequences of Bovine Respiratory Syncytial Virus. Virus Research. 24: 115-121.

187 Zamora M. \& Samal S.K. 1992. Sequence-Analysis of M2 Messenger-Rna of Bovine Respiratory Syncytial Virus Obtained from an F-M2 Dicistronic Messenger-Rna Suggests Structural Homology with That of Human Respiratory Syncytial Virus. Journal of General Virology. 73: 737-741.

188Zimmer G., Rohn M., McGregor G.P., Schemann M., Conzelmann K.K. \& Herrler G. 2003. Virokinin, a bioactive peptide of the tachykinin family, is released from the fusion protein of bovine respiratory syncytial virus. Journal of Biological Chemistry. 278: 46854-46861.

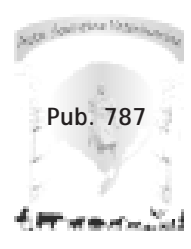

